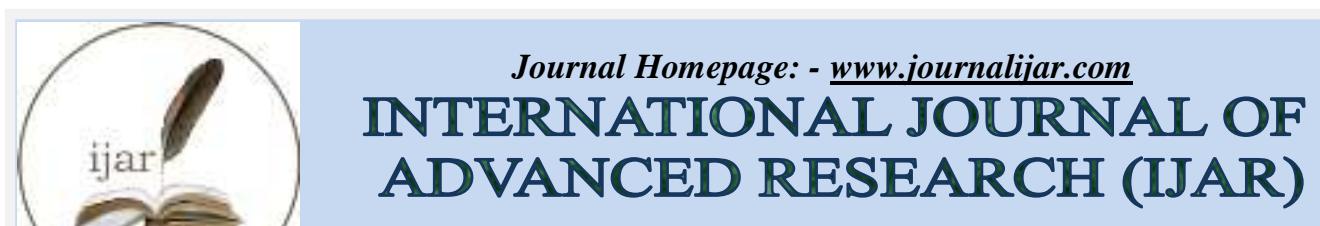

Article DOI: $10.21474 / \mathrm{IJAR} 01 / 5948$

DOI URL: http://dx.doi.org/10.21474/IJAR01/5948

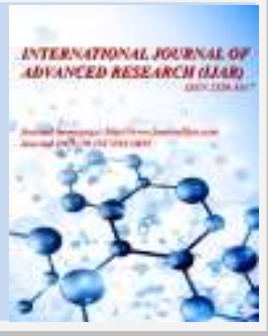

RESEARCH ARTICLE

\title{
A STUDY ON THE PROBLEMS AND PROSPECTS OF WOMEN LABOURERS IN UNORGANIZED SECTOR.
}

Dr. B. E. George Dimitrov ${ }^{1}$, S. Gandhimathi ${ }^{2}$ and K. Siva ${ }^{3}$.

1. Assistant Professor Department of Humanities, St.Claret College. Bangalore. Karnataka.

2. Full Time Research Scholar Department of Political Science and Development Administration. The Gandhigram Rural Institute - Deemed University, Gandhigram.

3. Full Time Research Scholar Department of Political Science and Development Administration. The Gandhigram Rural Institute - Deemed University, Gandhigram.

\section{Manuscript Info}

\section{Manuscript History}

Received: $x x x x x x x x x x x x x x x x$ Final Accepted: $x x x x x x x x x x x$

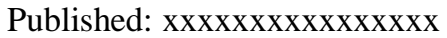

Key words:-

Unorganized, Spinning Mill, Health, Women, workers.

\begin{abstract}
Women are suffering from various forms of discrimination, like oppression, exploitation, degradation, aggression, humiliation. Women are considered as a commodity by the society which leads in to violating their rights. Violations are different in forms. In India, women constitute almost half of the total workforce. However, over 96 per cent of women work in the informal, unorganized sector. Overall, the formal sector constitutes 93 per cent of the workforce of the population of India. Moreover, these workers contribute 62 per cent to the gross domestic product (GDP), and 50 per cent to the national income. The female labour force constitutes one third of the rural workers in India. Women workers face serious problems and constraints related to work such as lack of continuity, insecurity, wage discrimination, unhealthy job relationship, absence of medical and accident care etc.
\end{abstract}

Copy Right, IJAR, 2017,. All rights reserved.

\section{Introduction:-}

In India, women constitute almost half of the total workforce. However, over 96 per cent of women work in the informal, unorganized sector. Overall, the formal sector constitutes 93 per cent of the workforce of the population of India. Moreover, these workers contribute 62 per cent to the gross domestic product (GDP), and 50 per cent to the national income. The female labour force constitutes one third of the rural workers in India. Women workers face serious problems and constraints related to work such as lack of continuity, insecurity, wage discrimination, unhealthy job relationship, absence of medical and accident care etc.

\section{Unorganized Sector:-}

The informal sector plays an important and controversial role. It provides jobs and reduces unemployment and underemployment, but in many cases the jobs are low-paid and they face job insecurity. Unorganized sectors play bolsters in entrepreneurial activity, and it is always considered as the detriment of state regulations compliance, particularly regarding tax and labor regulations. The size of the informal labor market varies from the estimated 4$6 \%$ in the high-income countries to over $50 \%$ in the low-income countries. It's size and role in the economy increases during economic downturns and periods of economic adjustment and transition.

Corresponding Author:- S. Gandhimathi.

Address:- Full Time Research Scholar, The Gandhigram Rural Institute - Deemed University, 
The concept of the informal sector was introduced into international usage in 1972 by the International Labor Organization (ILO) in its Kenya Mission Report, which defined in formality as a "way of doing things characterized by (a) ease of entry; (b) reliance on indigenous resources; (c) family ownership; (d) small scale operations; (e) labor intensive and adaptive technology; (e) skills acquired outside of the formal sector; (g) unregulated and competitive markets". Since that time, many definitions were introduced by different authors and the ILO itself. The ILO/ICFTU international symposium on the informal sector in 1999 proposed that the informal sector workforce can be categorized into three broad groups: (a) owner-employers of micro enterprises, which employ a few paid workers, with or without apprentices; (b) own-account workers, who own and operate one-person business, who work alone or with the help of unpaid workers, generally family members and apprentices; and (c) dependent workers, paid or unpaid, including wage workers in micro enterprises, unpaid family workers, apprentices, contract labor, home workers and paid domestic workers

Operationalizing the concept of informality for the purpose of measurement is not easy both because the two categories of the informal sector overlap and because the border between the informal and the formal sector is blurry. First, if unofficial earning strategies are exercised by a low-profit small enterprise with low quality working conditions, then workers of this enterprise and the enterprise itself can be classified as belonging to both informal market categories. An example of such a case is an unregistered one-person low-profit street trade enterprise - these characteristics combine unofficial and survival activities. Second, some formal market jobs or enterprises can be classified as informal if it is found that they have poor work protection or if the life style and opportunities they entail are considered undesirable. If the street trader from the previous example registers her enterprise, the enterprise and the trader herself could be categorized as belonging to the formal sector if the profit is considered above the survival level.

\section{The major characteristics of the unorganized workers:-}

* The unorganized labour is overwhelming in terms of its number range and therefore they are omnipresent throughout India.

* As the unorganized sector suffers from cycles of excessive seasonality of employment, majority of the unorganized workers does not have stable durable avenues of employment. Even those who appear to be visibly employed are not gainfully and substantially employed, indicating the existence of disguised unemployment.

* The workplace is scattered and fragmented.

* There is no formal employer - employee relationship

* In rural areas, the unorganized labour force is highly stratified on caste and community considerations. In urban areas while such considerations are much less, it cannot be said that it is altogether absent as the bulk of the unorganized workers in urban areas are basically migrant workers from rural areas.

* Workers in the unorganized sector are usually subject to indebtedness and bondage as their meager income cannot meet with their livelihood needs.

* The unorganized workers are subject to exploitation significantly by the rest of the society. They receive poor working conditions especially wages much below that in the formal sector, even for closely comparable jobs, ie, where labour productivity are no different. The work status is of inferior quality of work and inferior terms of employment, both remuneration and employment.

* Primitive production technologies and feudal production relations are rampant in the unorganized sector, and they do not permit or encourage the workmen to imbibe and assimilate higher technologies and better production relations. Large scale ignorance and illiteracy and limited exposure to the outside world are also responsible for such poor absorption.

* The unorganized workers do not receive sufficient attention from the trade unions.

* Inadequate and ineffective labour laws and standards relating to the unorganized sector ${ }^{\mathrm{ii}}$.

The unorganized sector covers most of the rural labour and a substantial part of urban labour. It includes activities carried out by small and family enterprises, partly or wholly with family labour. In this sector wage-paid labour is largely non-unionized due to casual and seasonal nature of employment and scattered location of enterprises. This sector is marked by low incomes, unstable and irregular employment, and lack of protection either from legislation or trade unions. The unorganized sector uses mainly labour intensive and indigenous technology. The workers in unorganized sector are so scattered that the implementation of the Legislation is very inadequate and ineffective. There are hardly any unions in this sector to act as watch-dogs. But the contributions made by the unorganized sector to the national income, is very substantial as compared to that of the organized sector. It adds more than $60 \%$ 
to the national income while the contribution of the organized sector is almost half of that depending on the industry ${ }^{\text {iii }}$.

\section{Women and Unorganized sector:-}

Millions of women all over the world has brought them as paid labour, but compared with men their workforce is far behind when it comes to unorganized sector. Whereas gender inequalities has made women at the lowest level of the global value chain which involves in less paid jobs, subcontracted work, insecurity of self- employment, denial of social protection. Half of the world women require access to decent living, quality of work, parental leave, maternity leave which is denied in the unorganized sector. On the basis of economic growth also if women play an equal role with men it can increase the GDP of US\$ 28 trillion by 26 percent by 2025 .

\section{Occupational Segregation:-}

Women are always allocated in lower paid ,less skilled work and higher risk of job insecurity.They are always under represented in decision makin in the fields of science and technology. In most of the service sectors women contibute the most 77 percent and 91.4 percent are respectively from East Asia and North America. Women workers vary from one part to another where lower and middle income groups are fully enegaged in agriculture sector. Higher level income countries women concentrate in health,retail and wholesale sector,mills, etc. Discrimination on the grounds of gender where sectoral and occupational segregation leads to poverty,inflexible working hours,lack of childcare, poor parental leave,etc.

\section{Wage Gap:-}

Globally women can make only 77 cents for every dollar as men earn. This is one of the lifetime inequality of income which will take over 70 years to cross over this gap with men. As women face greater responsibility within family,infelxible working hours, limited access to parental leave, which reduces the workforce of women to partime employement. They are highly exposed to inequalities of social protection,old age protection,etc. Whereas wage gap is larger for women with children in Sub Saharan Africa constitutes 31 percent and without children 4 percent ,35 percent with children and 4 percent without children in South Asia.

\section{Migrant Workers:-}

Migrant workers are the most vulnerable categories throughout the world among which women are highly engaged in economic and social well being within their homes and in overseas. Larger income comes to major countries through migrant workers which intern brings livelihood of millions and improves the economy.57 percent of women are globally engaged in domestic workers were they do not have time limitation on their working hours. Often women fall under the prey of agency, brokers, who hire illegally to other countries which sometimes results in human and labour rights violations. It is estimated around $\$ 581.6$ billion of income have been sent to their homes by migrant workers in developed nation and $\$ 431.6$ in developing countries.

\section{Violence Against Women:-}

Violence against women in work places is a common phenomena worldwide whether it is a developed country or developing country it doesn't differ but the level of violation differs. Out of 173 countries based on a study shows 114 countries have higher average of sexual harassment at work places. Though there are various laws and provisions to protect violence against women but their impact is very low. Violence against women would result in absenteeism, lapse of promotions, job insecurity, stress and mental disorders

\section{Social Protection:-}

Women face greater insecurity when it comes to labour market,as they earn low wages compared with men. They have less acess to credit and assets than men which sometimes has less coverage towards social protection ,pensiosn,insurance,etc. Around 65 percent of women do not enjoy retirement benefits which shows that 200 million women at old age do not enjoy social security compared with 115 million women.

From street vendors and domestic workers to subsistence farmers and seasonal agriculture workers, women make up a disproportionate percentage of workers in the informal sector. In South Asia, over 80 per cent of women in nonagricultural jobs are in informal employment; in sub-Saharan Africa, 74 per cent; and in Latin America and the Caribbean, 54 per cent ${ }^{\mathrm{iv}}$. 
Working in this informal, or grey economy, as it's sometimes called, leaves women often without any protection of labour laws, social benefits such as pension, health insurance or paid sick leave. They routinely work for lower wages and in unsafe conditions, including risk of sexual harassment. The lack of social protections has long-term impact on women. For example, fewer women receive pensions globally, and as a result, more elderly women are now living in poverty. Even in developed economies, such as in France, Germany, Greece and Italy, women's average pension is more than 30 per cent lower than men's ${ }^{\mathrm{v}}$.

\section{Problems of Women Labourers in the Unorganized Sector in India:-}

Unorganized sector work is characterized by low wages that are often insufficient to meet minimum living standards including nutrition, long working hours, hazardous working conditions, lack of basic services such as first aid, drinking water and sanitation as the work side, and the like. Education of women leads to occupational diversification. Education helps women to move away from spinning mill workers.

The women in the unorganized sector are able to manage the family by way of mental satisfaction, savings, Educating the children, and are able to take decisions. They could able to derive satisfaction by the proper utilization of time and are able to manage the family. Through savings, they could manage the family, educate the children, gain self confidence and economic independence. Education of children is possible by managing the family, savings and economic independence

In India, women constitute almost half of the total workforce. However, over 96 per cent of women work in the informal unorganized sector. Overall, the informal sector constitutes 93 per cent of the workforce of the population of India. Moreover, these workers contribute 62 per cent to the gross domestic product (GDP), and 50 per cent to the national income. This sector includes workers employed in a wide range of economic activities, from street vendors and casual workers in a mill workers permanent workers and temporary workers. However, unlike workers in the formal sectors, they do not have access to regular incomes or welfare benefits, making them extremely vulnerable to change and insecurity. The informal sector includes jobs such as domestic servant, small trader, artisan, or field labourer on a family farm. Most of these jobs are unskilled and low paying and do not provide benefits to the worker. The women workers in the informal sector constituted about 91.38 per cent. Similarly, among rural workers, about 92 per cent were in the informal sector.

The National Commission for Women estimates that 94 Per cent of the total female workforce is to be found in the unorganized sector. The growth of small and cottage industries has depend heavily on female labour. Likewise, Article 47, of the constitution requires that the state should regard the raising of the level of nutrition and the standard of living of public health, as among its primary duties.

* The elimination of all forms of forced or compulsory labour.

* The effective abolition of child labour.

- With a view to stimulating economic growth and development raising levels of living.

\section{Statement of the Problem:-}

Unorganized sector or informal sector do not enjoy much privileges of the organized sector especially when it comes to women it is fully biased with lots of economic disparities. It is difficult to organize unorganized workers as they are seasonal workers and part time players in each and every sector. Women are more vulnerable and are neglected in this sector where they are being exploited under various forms. The large segment of women faces the problem of job insecurity where they have to go in search of multiple jobs as they are paid less. The Constitution of India under the Article 23 which speaks about the right against exploitation. Though this is a fundamental rights which is always being misused under the unorganized sector where they are not paid according to the equal pay for equal wages. Long working hours without proper rest and exploited under bonded labour due to the ignorance of labour laws. Even the Supreme Court of India has over ruled that labours are hired below the statutory minimum wages which is considered to be equivalent to forced labour. The study mainly focuses on the problems and performance of spinning mill women labourers. The problems faced by women in spinning mills are often workers who migrate from various parts of the state of Tamil Nadu. They are exploited under various schemes especially women from tender age are chosen under a marriage scheme called Sumangali which is widely spread in all the spinning mills of Tamil Nadu. This scheme guarantees the women to get marital assistance when they work for a contract period. Many women who are in tender age join in these spinning mills based on this schemes were they are less paid and forced to work for long hours by the name of this scheme. 


\section{Objectives of the study:-}

- To study the socio-economic profile of women labourers in unorganized sector.

- To analyze the problems faced by women labourers in unorganized sector.

- To study the obstacles which are restraining women labourers in availing minimum wages.

- To explore various health issues and prospects of women workers in unorganized sector.

\section{Methodology:-}

This study was undertaken with the primary objective of studying the problems and prospects of women labourers in unorganized sector were spinning mill labourers were taken for the study. The study primarily has used quantitative method to investigate the research problem. Women labourers face various problems like health, less paid, not aware about labour laws. Most of them do not express their opinion freely and feel that they are insecure of their job. Most of them are not permitted to talk with outsiders on their own. The study was conducted in Dindigul district of Tamil $\mathrm{Nadu}, 100$ respondents were chosen for the study under various categories of socio-economic conditions.

Analysis:-

Table 1:- Age wise distribution of respondents

\begin{tabular}{|c|c|c|c|}
\hline S. No. & Age & Number of Respondents & Percent \\
\hline 1. & $18-28$ & 34 & 34 \\
\hline 2. & $29-38$ & 35 & 35 \\
\hline 3. & $39-48$ & 20 & 20 \\
\hline 4. & $49>$ & 11 & 11 \\
\hline & Total & 100 & $\mathbf{1 0 0}$ \\
\hline
\end{tabular}

Source: Computed

The above table shows the age wise distribution of respondents, 35 (35 per cent) respondents belongs to the age group of $29-38,34$ (34 percent) respondents belong to the age group of 18-28, 20 (20 per cent) respondents belongs to the age group of $39-48.11$ (11 per cent) respondents belongs to the age group of 49 and above. Hence the majority of 35 (35 per cent) respondents belongs to the age group of $29-38$.

Table-2:- Marital status of respondents

\begin{tabular}{|c|c|c|c|}
\hline S. No. & Categories & Frequency & Percentage \\
\hline 1. & Married & 74 & 74.0 \\
\hline 2. & Unmarried & 21 & 21.0 \\
\hline 3. & Widow & 5 & 5.0 \\
\hline & Total & $\mathbf{1 0 0}$ & $\mathbf{1 0 0}$ \\
\hline
\end{tabular}

\section{Source: Computed}

The above table shows the distribution of respondents based upon marital status, 74 (74 percent) respondents are married, 21(21 percent) respondents are unmarried, and 5 (5 percent) respondents are widows. Hence the majority of 74 (74 percent) respondents are married.

Table. 3:- Educational Status

\begin{tabular}{|c|c|c|c|}
\hline S. No. & Educational & Frequency & Percentage \\
\hline 1. & Illiterate & 10 & 10.0 \\
\hline 2. & Primary & 12 & 12.0 \\
\hline 3. & Middle & 23 & 23.0 \\
\hline 4. & Secondary & 28 & 28.0 \\
\hline 5. & Higher Secondary & 27 & 27.0 \\
\hline & Total & $\mathbf{1 0 0}$ & $\mathbf{1 0 0}$ \\
\hline
\end{tabular}

Source: Computed

The above table shows the educational status of respondents based on various categories, 28(28 percent) of respondents have completed their secondary schooling, 27(27 percent) of respondents have completed their higher secondary schooling, 23(23 percent) of respondents have completed their middle schooling, 12 (12 percent) of 
respondents have completed their primary schooling, 10(10 percent) of respondents are illiterates. Hence the majority of 28 (28 percent) respondents have completed their secondary schooling.

Table 4:- Family wise distribution of respondents

\begin{tabular}{|c|c|c|c|c|}
\hline S.No. & Particulars & Categories & Frequency & Percentage \\
\hline \multirow{3}{*}{1} & \multirow{3}{*}{ Family type } & Joint family & 12 & 12.0 \\
\hline & & Nuclear family & 88 & 88.0 \\
\hline & & Total & 100 & 100 \\
\hline \multirow{4}{*}{2} & \multirow{4}{*}{ Family members } & $1-3$ & 46 & 46.0 \\
\hline & & 4-7 & 43 & 43.0 \\
\hline & & $8>$ & 11 & 11.0 \\
\hline & & Total & 100 & 100 \\
\hline
\end{tabular}

Source: Computed

The above table shows the distribution of family type and members, 88 ( 88 percent) of respondents are from nuclear family, 12(12 percent) of respondents are from joint family. When it comes to family members distribution, 46 (46 percent) respondents are having family members of 1-3, 43 (43 percent) respondents are having family members of 4-7, 11 (11 percent) respondents are having family members of 8 and above. Hence the majority of 88 (88 percent) of respondents are from nuclear family and 46 (46 percent) respondents are having family members of $1-3$.

Table 5:- Income details of the Respondents

\begin{tabular}{|c|c|c|c|}
\hline S. No. & Monthly Income & Frequency & Percentage \\
\hline 1. & $1000-5000$ & 11 & 11.0 \\
\hline 2. & $5100-10,000$ & 57 & 57.0 \\
\hline 3. & $10100->$ & 32 & 32.0 \\
\hline & Total & $\mathbf{1 0 0}$ & $\mathbf{1 0 0}$ \\
\hline
\end{tabular}

Source: Computed data

The above table shows the distribution of women spinning mill workers based on income, 57(57 percent) respondents are having monthly income of Rs.5100-10,000, 32(32 percent) respondents are having monthly income of Rs.10,100 and above, 11(11 percent) respondents are having monthly income of Rs.1000-5000. Hence the majority of 57(57 percent) respondents are having monthly income of Rs.5100-10,00.

Table 6:- Source and Purpose of Borrowed

\begin{tabular}{|c|c|c|c|c|c|c|c|c|c|}
\hline S.No. & Purpos & 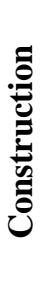 & 氖 & 葛 & 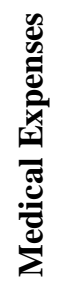 & 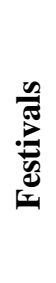 & 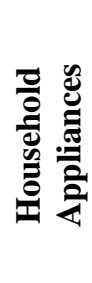 & & है \\
\hline 1 & Bank & 4 & 5 & 1 & & - & - & 2 & 12 \\
\hline 2 & Co-operative & 1 & - & 1 & - & - & - & 11 & 13 \\
\hline 3 & SHG & 1 & 20 & 1 & 6 & 4 & 8 & - & 40 \\
\hline 4 & Finance & 1 & 5 & 1 & 10 & 11 & 6 & - & 35 \\
\hline & Total & 8 & 30 & 5 & 16 & 15 & 14 & 12 & 100 \\
\hline
\end{tabular}

Source: Computed

The above table explains sources and purpose of the borrowed money by the respondents. The money is borrowed from the bank, cooperative, SHG, Finance, The purpose of borrowing the money is for construction of houses, education, marriage, medical expenses, festival, household appliances and agriculture. The source and purpose of the borrowed money is given below. 
Bank: Majority of 12 (12 percent) respondents borrowed money from bank for construction of houses, education, marriage, medical expenses, festivals, household appliances and agriculture.

Cooperative: majority of 13 (13 percent) respondents borrowed money from the cooperative for agriculture, construction of house, marriage.

Self Help Group: Majority of 40 (40 percent) respondents borrowed money from bank for construction of houses, education, marriage, medical expenses, festivals, household appliances.

Finance: Majority of 35 (35 percent) respondents borrowed money from bank for construction of houses, education, marriage, medical expenses, festivals, household appliances.

Table-7:- Distribution of respondents based on Health Insurance coverage

\begin{tabular}{|l|l|l|l|}
\hline S. No. & Health Insurance Covered & Frequency & Percent \\
\hline 1 & Yes & 10 & 10 \\
\hline 2 & No & 90 & 90 \\
\hline & Total & 100 & 100.0 \\
\hline
\end{tabular}

Source: Computed

The above table shows the distribution of respondents based upon the health insurance coverage, 90 (90 percent) respondents do not have the coverage of health insurance,10(10 percent) of respondents have health insurance coverage. Hence the majority of 90 percent respondents do not have health insurance coverage.

Table-8:- Distribution of Respondent face Health Problem

\begin{tabular}{|r|c|c|c|c|}
\hline S.No. & Health Issues & Yes & No & Total \\
\hline 1 & Diabetes & 12 & - & 12 \\
\hline 2 & Anemia & 5 & - & 5 \\
\hline 3 & Gynecological Problem & 29 & - & 29 \\
\hline 4 & High/Low Blood Pressure & 15 & - & 15 \\
\hline 5 & Asthma & 7 & - & 7 \\
\hline 6 & Back /Joint pains & 14 & - & 14 \\
\hline 7 & Noise Pollution & 7 & - & 7 \\
\hline 8 & Allegery/Skin diseases & 2 & - & 2 \\
\hline 9 & All the above & 9 & - & 9 \\
\hline & Total & 100 & - & 100 \\
\hline
\end{tabular}

\section{Source: Computed}

The above table shows the health issues of respondents, the majority of 29 (29 percent) respondents have gynecological problems, 15 (15 percent) respondents have high and low blood pressure,14 (14 percent) respondents have back and joint pain problems, 9 ( 9 percent) respondents have all the above mentioned health issues, 7 (7 percent) respondents have asthma and noise pollution respectively,5(5 percent) respondents have anemia. Hence the majority of 29 ( 29 percent) respondents suffer from gynecological problems which is most common among the women spinning mill workers.

Table-9:- Distribution of respondents based upon emotional symptoms

\begin{tabular}{|c|c|c|c|c|}
\hline S. No. & Emotional symptoms & Yes & No & Total \\
\hline 1 & Depression & 19 & - & 19 \\
\hline 2 & Anger/Frustration & 30 & - & 30 \\
\hline 3 & Fear/Anxiety & 34 & - & 34 \\
\hline 4 & Unwanted thoughts & 6 & - & 6 \\
\hline 5 & Difficulty in concentrating & 2 & - & 2 \\
\hline 6 & Short temper or increased agitation & 9 & - & 9 \\
\hline & Total & $\mathbf{1 0 0}$ & - & $\mathbf{1 0 0}$ \\
\hline
\end{tabular}

Source: Computed 
The above table shows the emotional symptoms of respondents, the majority of 34 (34 percent) respondents have fear and anxiety,30 (30 percent) respondents anger and frustration, 19 (19 percent) respondents have depression, $9(9$ percent) respondents have short tempers or increased agitation, 6 ( 6 percent)respondents have unwanted thoughts, 2 ( 2 percent) respondents have difficulty in concentration. Hence the majority of 34 (34 percent)respondents suffer from fear and anxiety which is most common emotional symptoms among the women spinning mill workers.

Table -10:- Distribution of Respondents Awareness about Minimum Wage Act

\begin{tabular}{|l|l|l|l|}
\hline Particulars & Opinion & Frequency & Percent \\
\hline \multirow{2}{*}{ Minimum wage act } & Yes & 11 & 11 \\
\cline { 2 - 4 } & No & 89 & 89 \\
\hline & Total & $\mathbf{1 0 0}$ & $\mathbf{1 0 0}$ \\
\hline
\end{tabular}

Source: Computed

The above table shows the distribution of respondents based upon the awareness of minimum wage act, 89(89 percent) respondents are not aware about the minimum wage act,11 (11 percent) respondents are aware about minimum wage act. Hence the majority of 89 (89 percent) respondents are not aware about minimum wage act.

Table-11:- Distribution of Respondents Awareness about Labour laws

\begin{tabular}{|l|l|l|l|}
\hline Particulars & Opinion & Frequency & Percent \\
\hline \multirow{2}{*}{ Labour laws } & Yes & 12 & 12 \\
\cline { 2 - 4 } & No & 88 & 88 \\
\hline & Total & $\mathbf{1 0 0}$ & $\mathbf{1 0 0}$ \\
\hline
\end{tabular}

Source: Computed

The above table shows the distribution of respondents based upon the awareness of labour laws, 88(88 percent) respondents are not aware about the labour laws, 12 (12 percent) respondents are aware about labour laws. Hence the majority of 88 ( 88 percent) respondents are not aware about labour laws.

Table-12:- Distribution of Respondents Awareness about Minimum Wage Act

\begin{tabular}{|l|l|l|l|}
\hline Particulars & Opinion & Frequency & Percent \\
\hline $\begin{array}{l}\text { Sexual Harassment of Women at } \\
\text { Workplace (Prevention) Act }\end{array}$ & Yes & & \\
\cline { 2 - 4 } & No & 100 & 100 \\
\hline & Total & $\mathbf{1 0 0}$ & $\mathbf{1 0 0}$ \\
\hline
\end{tabular}

Source: Computed

The above table shows the distribution of respondents based upon the awareness of Sexual Harassment of Women at Workplace (Prevention) Act, 100 (100 percent) respondents are not aware about the Sexual Harassment of Women at Workplace (Prevention) Act., Hence the majority of 100 (100 percent) respondents are not aware about the Sexual Harassment of Women at Workplace (Prevention) Act.

Findings:-

- $\quad$ The majority of 35 (35 per cent) respondents belongs to the age group of $29-38$.

- The majority of 28 (28 percent) respondents have completed their secondary schooling.

- The majority of 12 (12 percent) respondents borrowed money from bank for construction of houses, education, marriage, medical expenses, festivals, household appliances and agriculture.

- The majority of 13 (13 percent) respondents borrowed money from the cooperative for agriculture, construction of house, marriage.

- The majority of 40 (40 percent) respondents borrowed money from bank for construction of houses, education, marriage, medical expenses, festivals, household appliances.

- The majority of 35 (35 percent) respondents borrowed money from bank for construction of houses, education, marriage, medical expenses, festivals, household appliances.

- The majority of 90 percent respondents do not have health insurance coverage.

- The majority of 29 (29 percent) respondents suffer from gynecological problems which is most common among the women spinning mill workers 
- The majority of 34 (34 percent)respondents suffer from fear and anxiety which is most common emotional symptoms among the women spinning mill workers.

- The majority of 88 (88 percent) respondents are not aware about labour laws.

- The majority of 89(89 percent) respondents are not aware about minimum wage act.

- The majority of 100 (100 percent) respondents are not aware about the Sexual Harassment of Women at Workplace (Prevention) Act

\section{Conclusion:-}

In India, almost 92 per cent of the work force in the unorganized sector one- third of which are women and their dependents. Though the Indian Constitution guarantees equality of opportunity related to work, equal rights for livelihood, equal pay for equal work etc., The condition of women in the unorganized sector is deplorable. The most serious hazard faced by the working class in the era of globalization is the increasing threat to job security. The informal sector is fast expanding, while the organized sector is shrinking. Contract, casual, temporary, part-time, piece-rated jobs and home based work etc., decreasingly replacing permanent jobs.

\section{Reference:-}

1. CBWE http://www.cbwe.gov.in/training-activities/unorganised-sector.aspx

2. Gupta. R.,(2009). "Perceived Caregiver Burden in India : Implications for Social Services". Affilia,24 (1), 69 79.

3. Vinita Shah,(1999) "Women Building Workers - An Area Study in Bombay NICMAR ISBN (81-85448-248)."Sexual Health Problems and Treatment seeking Behaviour Among Rural Women in India". International Conference AIDS, July 11-16; 15, Abstract No. C11462. International Institute for Publication Sciences, Mumbai India.

4. Purushothaman, Sangeetha., (1998). "The Empowerment of Women in India: Grassroots Women's Networks and the State", New Delhi: Sage Publication.

5. Times of India. "Protest Against Atrocities in Women", Internet.P.3.

6. Dev, Mahendra. S. (2006), " Growth -mediated and support led social security in the Unorganized Sector in India". Centre for Economic and Social Studies (CESS), Hyderabad (mimeo).

7. Peter Perman, Rajee Ahuja,(2008),"The Role of Government in Health", Economic and Political Weekly, June 28-July 41,Vol.XIII, No.26.

8. The Hindu, 2010,'Labour Conference and Protection of Workers rights", February 16, p11.

9. Government of India (2002 a ),"Report of the study group on Social security, Commission on Labour", Ministry of Labour, New Delhi.

ii.Government of India (2001) An overview of Unorganized Labour http://pib.nic.in/archieve/lreleng/lyr2001/rsep2001/18092001/r1809200113.html

iii.Ministry of Labour and Employement, Government of India, Unorganized Sector,http://cbwe.gov.in/trainingactivities/unorganised-sector.aspx

${ }^{\text {iv }}$.UN Women, Progress of the World's Women 2015-2016. Chapter 2, p. 71

v.UN Women, Progress of the World's Women 2015-2016. Chapter 3, p. 147. 